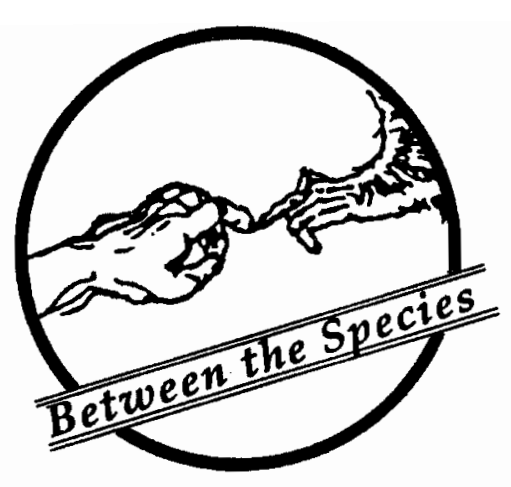

\title{
OPERATION MERCY: The Parable of the Computer
}

George Abbe

Plattsburgh, New York

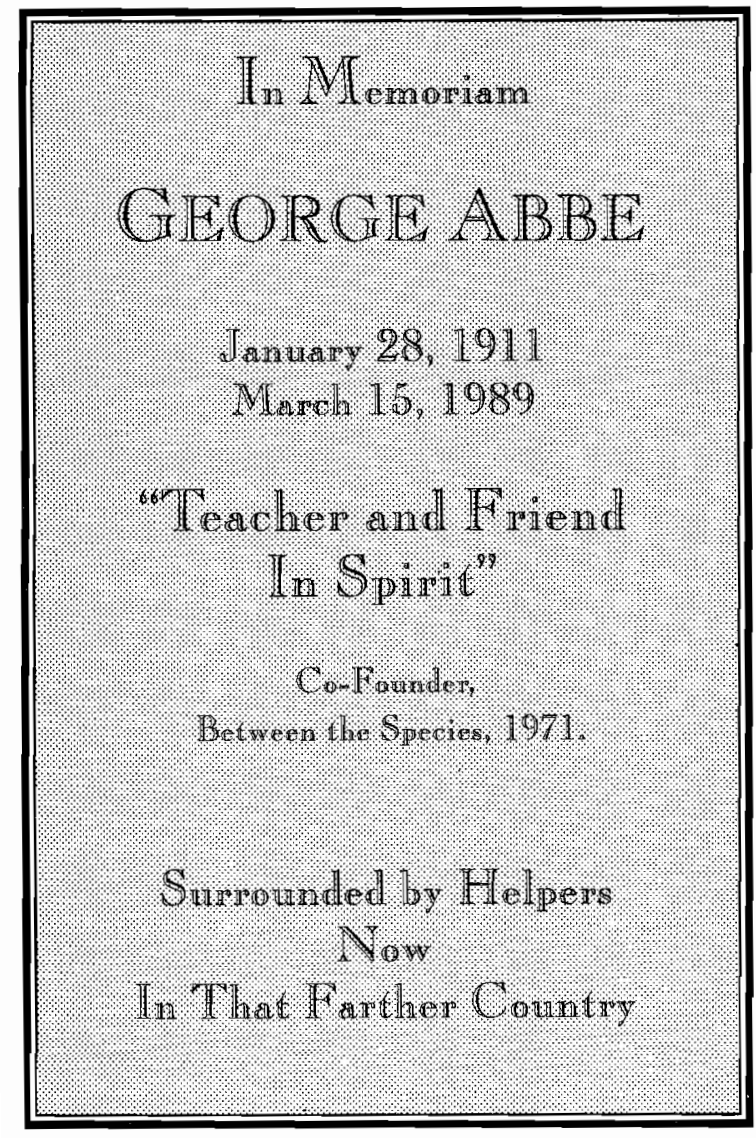

\section{Conclusion}

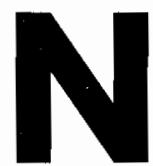

ot far from Jory's town there was a long stretch of flat fields at the base of a range of low hills, and Mr. Usher paid the farmer who owned these fields a handsome sum indeed for the privilege of launching and landing his rockets on his land.

There was, of course, always danger of a rocket going out of control and hitting some home or setting fire to some innocent neighbor's property or crops. The farmer who made the deal with the Ushers was told he was a true patriot, serving his country nobly by helping boys learn about the science that would put the U.S.A. on the moon first.

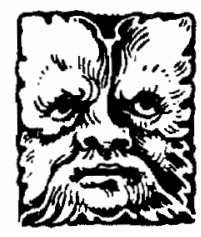

FICTION 
The initial launching - of two mice - by the Usher children a year ago, had won national fame, and the animal crew had been tagged "The Moustronauts." Both had died in the flight. The present launching, everybody said, was a step ahead - three hamsters who had been widely photographed. Somehow people felt hamsters were more nearly human than mice.

The Ushers, of course, were on their own. There was no adult scientific organization that would sponsor them because they were not subject to any top-grade checks or safeguards. Everyone thought it was "wonderful" to have kids fooling around and imitating the adult space-feats, but no one would insist on adult responsibility. Even the State Fire Prevention Service, which attempted to step in and require a license, got nowhere.

On the way to the big event, Jory, Mike, Mr. MacMahon, and Father Wilkins had to get out and walk, finally, the crowd was so huge and the unpaved farm road so narrow. Mr. MacMahon was a tall, lithe, intense fellow, with sharp brown eyes, a cool, humorless, aggressive face, and leathery flesh, who enjoyed great influence and social status in the region. As they walked along, he thrust forward fiercely, waved his hand at the crowd.

"American curiosity-seekers."

"Yes," said Mike, "the world's most sordid sensationalists."

"It wouldn't be so bad," the lawyer went on, "if such experiments would do any good. But everything the kids will learn is already known and it is pointless repetition, pandering to the American child, the most spoiled and overprotected youngster in the world."

"And to amuse them," said Father Wilkins, "as in medical research, some innocent animals must die."

He looked as though he nodded sleepily, even as he hastened, loose and long-striding, to keep up with his friends.

The crowds stood in the dirt road outside the barbed-wire fence and waited impatiently for the firing.

Mr. MacMahon, who was a leading candidate for office of District Attorney, walked up to a guard at the entrance of the field.
"Oh, hello, Mr. MacMahon," the guard said jovially. "Go right in." And then he saw the clerical collar on Reverend Wilkins. "... and Father, too," he added.

"I'm an observer for the Humane Society," said Father Wilkins.

"Of course ... and these others?" the guard said.

"They're in our party."

They were all admitted, and stood close behind the rocket as preparations were made. Mr. MacMahon had kept his camera in a large cloth bag. He now took it out, went up to the rocket, and as the Usher boys and their father proceeded to transfer the hamsters from their living-quarters box, the lawyer took pictures. The Ushers enjoyed it - smiled and strutted. This was what they did this for - fame.

"Are the TV cameras ready?" one of the Usher boys called. A major TV network was carrying the launching. Mr. Usher had made sure of that.

At the last instant, one of the boys noted that a hamster looked lethargic and ill.

"We'd better use mice," he said. "We've got stand-ins who are all trained and ready."

And so mice were substituted.

The dramatic moment arrived: the rocket soared toward the hills, carrying its realistic, living crew. The Usher boys were as fond of the mice as they were of the hamsters. All these animals they had cared for and put through their routine so long.

"Joey, Billie, and Dove will come through!" the older boy cried. "They'll do it, - just like people."

But something went wrong. The rocket's trajectory was too low; it wavered, began to fall; and suddenly, out of control, it plummeted into a field a half-mile from the farmhouse.

Mr. Usher stared, incredulous, and his sons, Arnie and Wayne, burst into wailing shouts of horror, protest, and anger. Then they were running with their father toward the smashed rocket.

But Mr. MacMahon was ahead of them; he was already dashing across the open field, movie camera clutched carefully in both arms. Behind him ran Jory and Mike, and lagging in the rear, trotting bravely, Father Wilkins, who was not young and spry enough for a long sprint. 
When they got to the wreckage, the three mice were lying in the open, crushed and bleeding. $\mathrm{Mr}$. MacMahon took pictures at once.

"Perfect evidence," Mike exulted. And he clapped Jory on the back.

Jory was overwhelmed with excitement, outrage at the death of the animals.

And Father Wilkins, still puffing and blowing from his unaccustomed exertions, exclaimed:

"This will do it! It's what we expected. And now we have the proof for a court of law."

"My God!" said Jory. "Look how mutilated they are!"

The Usher boys now came running up. They took one look at the murdered mice. They threw each other a quick look. The older one turned to the AP and UP and local newsmen who had run here on foot, close on the heels of Mike Dacey.

"Those mice," the young scientist declared, "aren't ours at all. They don't belong to us."

"How did they get there, then?" the AP man asked.

"I don't know," the boy replied. "But they aren't the ones we sent off." He was pale but sharp-eyed.

The father, Mr. Usher, was fuming.

"Of course they aren't ours," he said. "Someone who got here first put these corpses down and took off our live mice. We didn't kill them. We couldn't. Our rocket just had bad luck. But we didn't kill a thing. Someone's trying to get us into trouble."

Red-faced and defiant, he stared all around at the quiet gathering.

Mr. MacMahon looked at Mike, and then at Reverend Wilkins. Jory's amazement turned to a deep queasiness, a sickness of revulsion that became actual nausea. Was it possible? Yes, it was obvious: the Ushers had rehearsed this response in case of disaster. They disowned their own moustronauts, - the creatures who had suffered infinite torment in training and now had sacrificed life itself for their greater notoriety.

"Did you ever see such cynicism?" Mike said loudly and angrily. "--such degenerate corruption. To actually prepare this transparent lie! These people are the lowest of criminals."

The Ushers did not turn around to look at Mike.
"We have the evidence of needless murder," said the legal representative of the Humane Society, Mr. MacMahon.

He completed his shots of the dead animals, covered his movie camera meticulously, and started back. Mike and Jory and Father Wilkins followed.

But then occurred one of the greatest ironies imaginable. The Ushers were not the only criminals in the affair. Mr. MacMahon, who had taken the pictures to establish their guilt, proved to be a worse criminal himself - as morally revolting as any plug-ugly in jail.

Now, Mike Dacey had hoped to exploit this whole rocket business as a background for a big campaign to boost the computer as a substitute for live animals in experiments. For, if you could take the most widely-known example of callousness such as this nationally televised wanton killing of helpless creatures in a toy rocket, and switch it around to the advantage of the humanitarian - "See what happens when you put permissiveness, science, material values, idolizing of our children before compassion and humanity mangling the mice that had become pets to these young 'researchers'" - if you could exploit this farce, this tragic atrocity in a big ad in the New York Times and elsewhere-

"No animals need to die in scientific experiment, whether it is by adults or by children. The computer - along with tissue culture and other means - is the New Savior; it can do all experiments more precisely, more economically (dollar savings in the billions) and without the frightful waste of animal life."

-if you could use this fiasco shrewdly enough through such publicity, you could make a big break-through in community awareness and toward Government requirements that all applications for grants to do experiments contain two sets of figures - those representing the expense if the old, outmoded, whole-animal type were undertaken; and those showing costs of the thrifty, humane, non-animal, up-to-date method.

Mike had hoped to exploit this whole affair for the glory of compassion and the computer, the salvation of the tortured - and one of the most important elements in the whole campaign he could now wage against the vivisectionists and the 
pigmy-souled grantees and the Medical Establishment who didn't want to bother to train men in the use of the computer even if billions could be saved in life and money, didn't want to change at all, but insisted on using animals because it was familiar and easier - the key item in this attack would be photographs from the film taken by $\mathrm{Mr}$. MacMahon, official lawyer for the Humane Society, and, according to his political speeches, next in line for the job of D.A., friend of all the world's friendless, and, along with the Democratic Governor, custodian of man's morals, pocketbook, and private happiness.

"It's simple," Mike said to Jory. "All we have to do is use shots from the film to run in our ad: after that film has convicted the Ushers in the trial:

"-you can imagine the ad, the three mangled bodies:

"'This is what happens when we don't care what we do to our friends in nature."'

"Right!" Jory exulted. "It's terrific! I can't sleep nights, I'm so excited by winning this big battle for the tortured animals. Operation Mercy!"

"Come along to MacMahon's office with me," Mike said. "He's undoubtedly had the film developed by now."

But when they went there, Mr. MacMahon very coolly, very smoothly advised them they couldn't have the film. It was not available for anyone. "Aren't you going to prosecute, to use it for evidence?" Mike said.

"I don't know."

The lawyer was evasive, short in his comments. Finally, he excused himself. And Mike and Father Wilkins never did get the film. No one ever saw it.

Then occurred another extraordinary development. The Humane Society received a bill from Mr. MacMahon. Father Wilkins couldn't believe it. He came to Mike. For once he didn't look sleepy.

"How much would you say the services of Mr. MacMahon were worth on that one day of the launching?"

"In view of the fact he's legal counsel for a humane society, a non-profit, public service which has nobody, not even a clerk, making a nickel for help rendered, nobody on a payroll and all volunteers, I'd say he should gladly give his services for nothing."

Father Wilkins nodded.
"I'd agree." He held out a sheet of paper. "Here is a bill for $\$ 600.00$."

Mike literally gasped.

"It can't be! It's incredible! It's a joke."

"No; he's serious."

Then, stage by stage, it became clear why Mr. MacMahon had backed off. He was ambitious, in the running for the job of D.A., and already a big wheeler-dealer who planned to be the biggest. His public image would be badly tarnished if he came into court to protest the murdering of mere mice and to press charges against youngsters admired by space-minded Americans from coast to coast.

"I'm not a crusader," Mr. MacMahon admitted.

And so he pulled out. He was curt and cold about it.

"He must hate himself," Mike remarked, "to abandon a civic group trying to stop cruelty."

Father Wilkins pleaded with the lawyer; Mr. MacMahon refused. The source of the evidence would be known; he'd be badly clobbered by the critics, torn by the political wolves.

The Humane Society paid $\$ 400$ - about all they had in the treasury, a gift of a wealthy woman - to cover part of the bill!

"And not another penny will we ever pay to that scavenger," said Father Wilkins.

"You were a fool to give him that much," Mike snorted.

As much as these events depressed them, Mike, Father Wilkins, and Jory were not defeated, or even in despair.

"There's a way to lick them yet," said Mike.

Representing Vandon, his computer company, he went to Washington, D.C. Jory went with him.

"We'll tell them," said Mike, "that you belong to a Humane Society - which you do: Father Wilkins just made you an honorary member."

"Great!" enthused Jory. "I'll be an observer for my classmates."

"And for the younger generation, in general," Mike said.

In Washington, they went to the offices of their Senators and Representative. Mike hammered at one theme:

"The American public is fed up. They know more now about waste of animals, time, and money in these senseless experiments; and they are now economy-minded. We can save millions of 
dollars by insisting on just one thing - that each proposal to the National Institutes of Health for a grant for research carry two sets of figures - the one showing the cost if the long-established methods using whole live animals were followed, and the second, giving the cost if the new methods were adopted, - simulation, tissue culture, etc., which did not use whole animals.

"The results," Mike told his listeners, "would be sensational and overwhelming. Nobody would have to call anybody any names. Scare techniques would no longer be needed. The humane societies would not have to fight this issue any more; they'd get what they've been struggling for, for a century - by hammering at one thing.

"By the simple expedient of revealing how much cheaper and more efficient the new is than the old - by recording the differences in black and white - we force the biologist, the medical scientist, to begin training himself in the exact sciences - math, physics, engineering - so he can use the computer, adapt it to all specific studies, so he can use mathematical models, tissue culture, etc., as substitutes for the living creature who now, under our outdated regime, must die so horribly."

The political people listened and were impressed. They promised to look in to the matter, and one Senator committed himself to inserting into new lab-animal legislation soon to come up, this exact provision - the requirement that all proposals for grants contain these two sets of figures.

Next, while Jory sat and listened, entranced, Mike presented the same recommendation to $\mathrm{Mr}$. Grayson, the man at N.I.H. who was in charge of the Division of Simulation. Mr. Grayson was sympathetic with Mike's view.

"We do not like to have to use animals, you know, in any of the experiments supported by the Institute."

And he went on to explain how N.I.H. passed out, each year, two billion dollars of taxpayers' money for research. Practically no scientists used the computer yet - tradition, vested ideas and interests too strong: too much trouble to learn over, just to save animals and dollars and as long as the Government would go on pouring out the dough for the old ways.
"The public," Mr. Grayson said, "doesn't realize how much we, at the Institute, would like to change. In fact, so committed are we to trying to find other methods, simulation, tissue culture, etc., that we tack an offer onto each grant we confer $-5 \%$ of the total will be added if the grantee uses the new substitution methods."

"You do?"

"Yes. But the trouble is - practically nobody takes us up. Too difficult. They're not trained. So they just don't get the extra money."

"What we need, then," said Mike, "is a vast training program in the precise sciences to prepare us for a switch to the substitutes, simulation, etc."

"Exactly. And if you will find, as a starter, a medical center or a nursing home with space somewhere that will utilize the new medical equipment in this line, computers, etc., and develop a big training program for scientists of this kind - which will benefit not only humane societies and animals, but science itself, in incalculable ways - if you will do this and contain all these facts and petitions in a proposal of your own, I will say, quite frankly, though off the record, that we will be more than glad to consider it."

Jory felt a chill of joy, of wonder and pride, steal along his backbone.

"Then my Government isn't completely against us," he thought to himself. "The N.I.H., which decides all these experiments, is actually trying to get scientists to use something other than animals! They will help us promote a whole training program to that end! It's wonderful. I can't believe it. I'm proud, now, to belong to this country."

And he forgot to fidget nervously in his chair, in that glistening conference-room of the N.I.H., at the end of the long glossy-shining table, and he spoke boldly:

"It's wonderful to think the Government is really on the right side in this -- that you encourage simulation and other methods that don't use animals."

The Director smiled.

"I'm glad something's good about this Government," he said.

And they all laughed. 
In New York City, Mike and Jory visited United Action for Animals, Inc. - the most important organization in America," Mike called it, because it had been the pioneer in research and education regarding the new substitutions.

"It's a small outfit," he said, "but Miss Seiling, the woman who runs it, is a wizard, a saint, a dedicated, noble person." And soberly he added, looking the boy in the eye: "Miss Seiling is the sort of individual, Jory, that long ago made this country what it is - or what it used to be. Few of her kind of fighting idealists are left. Everyone now is a pimp for some monied group. Miss Seiling has little money, but a great will and a great spirit. You'll be fortunate to meet such a woman."

They visited Miss Seiling at U.A.A., and to Jory she was every ounce as remarkable as Mike had said. And there they all wrote the copy for a New York Times ad: and it was mailed in, and appeared two weeks later.

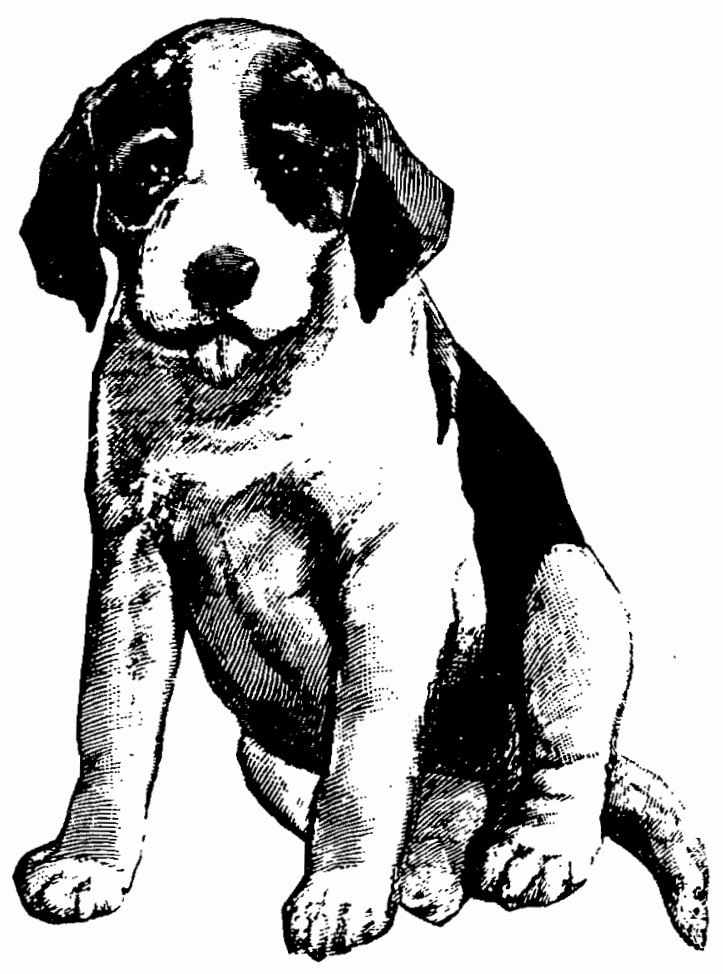

What a thrill it was to open up the nation's leading newspaper and see all those words, those pictures, leap up at him, that ringing appeal for a cause which he himself had championed among friends and acquaintances and had watched materializing in ad form at the office of U.A.A.

Their Times publicity brought in a fair amount of money. They ran another ad: Under the heading: "The Lucky Ones Die Quickly," was a picture of a dog lying on the wire mesh floor of a lab cage, his face staring in glassy-eyed agony. Then the message: "Once the lively favorite of a warm and living family, Duke lies near death, crying alone in a research laboratory. Millions of other animals every year are subjected to mass experimentation which is supposed to improve human health. The lucky ones die quickly. The others, like Duke, suffer for days, weeks, months, or even years. None comes out of the laboratories alive. The irony of this mass suffering is that the same experiments can be done - and done better - by what is called Computer Simulation, which simply means that the researcher can perform his experiments mathematically and obtain answers to his questions by the aid of a computer. The heart, kidney, lungs, nerves, eyes, blood, arteries - all can be construed mathematically and studied in both normal and diseased states.... Often the computer gives new information which never could have been discovered in live animals. And this research can be done at a fraction of the cost of animal experimentation. But the experimenters are not trained in these new methods; urge the Department of Health, Education, and Welfare to set up training centers. 'The great majority of biologists, including some very good ones, simply do not have enough mathematics to understand what the simulation people are talking about' reports the Second Cybernetic Sciences Symposium."

They ran another ad. Under the heading "Science vs. Savagery" were pictures of monkeys locked in steel vises so no part of the body could be moved, and the caption read: "They never leave this vise during their lifetime -8 or 9 years, or longer." And there were pictures of puppies on wide-mesh cage-floors with one foreleg gone. Caption: "From standing in one position so long, their claws grow around the mesh floor. To free 
themselves, they chew off the leg." Contrasting with these were pictures of computers doing simulation.

Then the message: "Today, the powerful and sophisticated techniques of the mathematical sciences provide a better way to obtain medical knowledge than mass experimentation on animals. Yet animal researchers continue to spend hundreds of millions of taxpayers' dollars every year on obsolete, repetitious, and unproductive animal experiments. (More than 80,000 animals are being experimented on at the Davis branch of the University of California). A distinguished authority on preventive medicine at Harvard Medical School deplores the fact that "this enormous expansion in our national medical research program, together with our lagging national health picture, is the paradox of modern medicine." A scientist at Hadassah Medical School puts it this way: "The education of the average biomedical researcher is obsolete as far as physical, engineering, and mathematical disciplines are concerned. One cannot, however, study the performance of a bio-system without the tools provided by these disciplines." Only informed public opinion will cause the diversion of taxpayers' funds from animal experimentation to the techniques of the exact mathematical sciences - and at the same time provide a more scientific health program."

This ad brought in the most money of all, but not yet enough to cover the cost.

Meanwhile, Mike and his associates at the Vandon Computer Company had been doing some research, and they now came up with the best pitch yet - two cases of experimenters who had refused to use non-animal methods even when bids had been made by computer companies that were far lower than the submitted costs of the old methods. In both cases, the labs had gone ahead with the higher-priced project because they didn't have people trained in the new techniques.

"Only a law can make them train," said Mike.

Eleanor Seiling wrote a letter of jubilation to Father Wilkins and Mike Dacey:

"For the first time our ad has paid for itself. Money is coming in from all over - hundreddollar checks, two hundred-dollar checks. We've broken the barrier! We're flying!"

Jory was as elated as Mike and Father Wilkins.

He wanted to help in some special way.

"I'm going to figure out how to reach the high schools - big," he said.

An event occurred which greased the wheels.

The two Usher boys had continued their rocket experimentation, in spite of increasing criticism from newspapers and humane groups; and one day they took a five-months' old puppy of their father's favorite bird-dog, put him in a rocket without Mr. Usher's knowledge, and sent him up.

The rocket crashed, killing the puppy.

The father, who idolized his hunting dogs almost as much as he did his sons, was heartbroken.

Then came a heavier, unbearable blow; one of the Usher boys, Wayne, during his experimentations, got a bad burn which became infected. He was dead in two days.

This crushed the father so that he was deathly ill for a week. When he finally recovered, he was a changed man. And, ironically, the first thing he did was to come to Father Wilkins.

"Father," he said, "I grew up in a religious family, even though I haven't gone to church for years. The death of my dog and then my son has shocked me. I realize how bad all this publicityseeking, this waste of animals, has been. I want to make up for it.

"Now I have a lot of money. And, in memory of my son, I'd like to contribute a sizable sum to a project for animals, not against them."

Father Wilkins' eyes shone.

"I've got just the person and the project for you," he said.

He phoned Jory.

"Jory. Run over here and see a new friend of ours. Mr. Usher."

"Mr. Usher!"

"Yep! That's right."

Jory came. And Father Wilkins, although his eyelids kept drooping and his head kept nodding as he talked, explained what he had in mind:

"Jory, you want to do something special. Now here is a sum of money, a gift we could use for a Youth Army - Operation Mercy. You can organize it. And I wouldn't be surprised if Mr. Usher would help. 
"I certainly will," said Mr. Usher. "And it will be a pleasure to be saving lives, for a change, instead of destroying them."

Jory's face was illumined, ecstatic.

Suddenly, he snapped his fingers.

"And now I see the first move we've got to make!" he exclaimed.

"What?" asked Father Wilkins.

"A March on Washington!"

\section{There will come a}

time when the

world will look

back to modern

vivisection in the

name of science as

they do now to

burning at the stake

in religion.

Aided by Mike, Father Wilkins, and Mr. Usher, Jory directed a nation-wide educational campaign, explaining about the revolution in laboratory methods - a revolution that would release millions, and eventually billions, of animals from bondage, torture, and death. He pleaded with the students at his own high school to follow him in a mammoth march at the Capitol which would, in the words of the appeal he and Father Wilkins and Mike composed and disseminated throughout the schools of the country:

"...compel the legislators to incorporate into the new lab bill the requirement that the comparison in costs between animal and non-animal methods always be included in any application for funds."

Never had Jory known such excitement, exaltation. He was able to get many of his own friends to look on the project as a fabulous adventure, a great new game, more rewarding than football, because, as he put it:

“...when it's won, we're not just tired and sweaty and relaxed; we've saved millions of innocent creatures!"

To which Mike added:

"The hippies have fun protesting and amusing themselves; we have more fun saving other living things, helping the Switch to the Computer, the Biggest Revolution in the history of religion -because this is a religious thing - this is our service to world progress - to blast-off the greatest act, The Salvation of the Helpless, The Rescue of the Trusting and the Doomed."

Jory picked up the word "Rescue."

"You know how they think up names of organizations based on the letters in a word forming the initials of the full title of the organization? Well, we ought to be able to do something with that word 'Rescue." "

"You're right. It would be a good name," said Father Wilkins: "-a broad, national outfit, both youth and adult, which could sponsor this March, and later on, other projects."

And once again, between the three of them, they came up with a good publicity twist.

"R.E.S.C.U.E. - Research Education for Substitutes for Creatures Used in Experiment."

And so, in the March on Washington, at the front of each squadron of poster-carrying crusaders, they displayed one huge sign bearing official identification:

THE YOUTH ARMY: OPERATION MERCY auspices of R.E.S.C.U.E. (Research Education for Substitutes for Creatures Used in Experiments).

The 1,200 marchers carried a host of placards - challenging, inspiring, ingenious. One of the foremost - and largest — read:

"FROM MONSTER TO SAVIOR"

"FROM MENACE TO EPIC HERO"

Cartoons on the left showed animated computers, first, with a ruthless, demonic face and arms spread out to embrace and crush a cowering multitude of people, and, second, with a Dracula countenance, sucking the whole earth in to his 
steel computer guts; cartoons on the right showed, first, a computer with a benign, radiant face, kneeling down and releasing great swarms of creatures from a burning, smoke-billowing cage marked "TORTURE," and, second, the same figure of the Savior, the Redeemer, standing tall, powerful, refulgent, with the wreath of the victor, the Hero, upon his brow, and his arms held out, palms outstretched, in benediction and protective love, over the entire earth crowded with all its different creatures.

Then came other posters: Each one had a picture of a computer with a face, a halo and angel wings.

"The Big Crusade - The Switch to Simulation."

"The New Religion - Mercy. The New Salvation - of Billions of Lives."

"An Empire of Compassion - Not SelfAmbition."

"Mercy is Greater than Knowledge."

"Pity is Stronger than Wisdom."

"The Youth of Our Nation Proclaiming - Not Power, but Love."

"The Great Religious War vs. Savagery in Our Labs."

"Not the Exploitation of Nature, but Cooperation with Nature."

And, on many placards displaying the New York Times ad photo of the dying dog lying on the wiremesh floor of a lab cage, eyes glazed in final anguish:

"Help the Helpless; Fight for the Weak, the Voiceless, the Underdog."

Jory and Father Wilkins and Mike led the long column back and forth in front of the White House several times, then along the margin of the park fronting the Capitol Building. It was to prove the most overwhelming, stupendous day in Jory's school-boy years. Father Wilkins, bareheaded, addressed the far-flung, quiet assembly of boys and girls. He quoted from the U.A.A. ads in the Times; he read a letter from a scientist in California:

"Already, partly due to the efforts of your organizations, U.A.A., Inc., and RESCUE, partly to the encouragement by the Department of Simulation of the National Institutes of Health, I have seen four cases of researchers who are abandoning the use of animals in their projects. One writes: 'I'm sick and tired of squandering life.' All four are adopting mathematical models or tissue culture."

Father wilkins looked up and turned his gaze slowly and penetratingly back and forth over the crowd, into the eyes and minds of the nation's future leaders.

"And this is just the beginning," he said. "This early trickle will become a stream, a flood. And in your generation, when you are in control of our nation's destiny, the practice of vivisection, what Gandhi called 'The blackest of all black crimes that man is at present committing against God and His fair creation,' will be a thing of the past.

"As Dr. Henry J. Bigelow of the Harvard Medical School put it:

" There will come a time when the world will look back to modern vivisection in the name of science as they do now to burning at the stake in religion.'"

Father Wilkins raised his hand as though bestowing a benediction.

"And you, my young friends and comrades, are the pioneers in this vast moral and religious change - the release of billions of creatures from agony and death; you are the crusaders of the most glorious, salvation-giving Event in our country's history - The Youth Army Operation Mercy."

And the great cheer that rose from the assembled Army shook Jory's heart, racked him with indescribable joy. He felt light-headed, then weak-limbed; he felt cold, then burning hot with the exultance of victory.

And he watched as Father Wilkins sat down next to Mike Dacey on the platform. Behind these two friends towered the white dome of the Capitol. And then Jory realized it was his turn to speak next. And as he was being introduced by Mike, he saw Father Wilkins' eyelids drooping, his head nodding, and that familiar gentle, benign, compassionate expression shade off into sleepy contentment, trust in the overbrooding Watcher.

The clergyman's chin, for a moment, touched his chest - then, quickly, he jerked his head up, forced his eyes open.

Jory grinned to himself.

"He's got good reason to fall asleep this time," he thought: "—after all the hard work he's done to organize this March. Good old Father Wilkins!" 
As he went to the podium to speak, he saw the brotherly salute to him in the eyes of the priest, the tribute and encouragement to a fellowwarrior. And he was strengthened, confident. The nervousness slipped away. He felt raised up, as on the broad palms of giant, benevolent force, a concern for all the world's teeming variety of creatures, all its multitudinous love-created life.

And he heard his voice soaring out over the listeners:

"And the Bible says: 'A sparrow does not fall without His knowing and caring.' You and I are sharing that spirit a million, a billion times over, by the lives we rescue. We are sharing that Perfect Compassion."

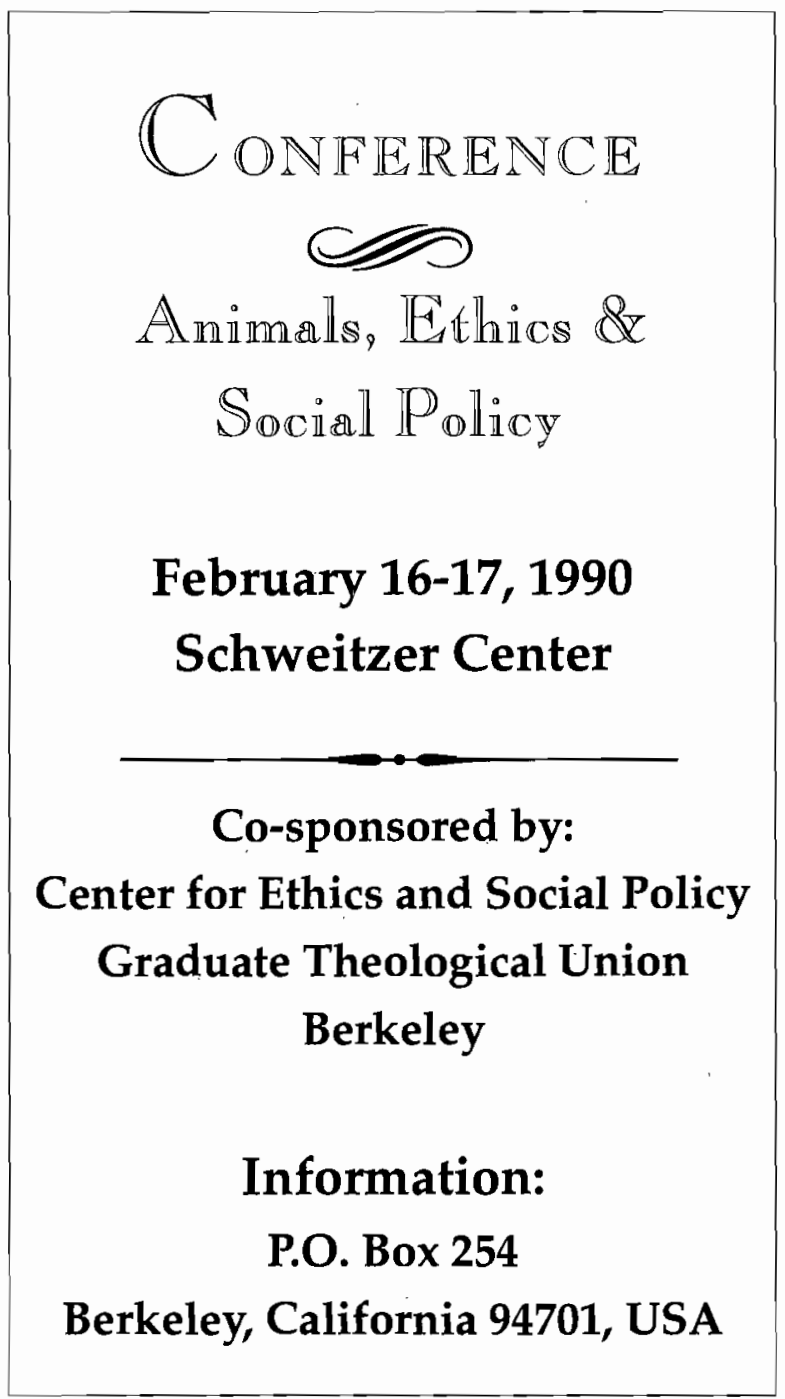

\section{For Love of this Earth:}

$\mathbf{G}$ rief is so near the surface

That often I dare not speak

For fear

The words would come

In great shuddering sobs

And they would call me

Madwoman

And not listen

To what I have to say.

For I would shout it from the mountaintop

Behold: A Mystery.

Earth is so fair.

There is more beauty

Than your heart can ever hold

In a swan's neck, a raccoon's hand

In the song of a thrush

In sunlight through leaves in thick, green forests

In the wind on the water's skin

In the agony of birth.

Cherish it

For you are part of it

This fragile blue-green planet

It flows through you

The living blood of Earth.

And for love of this Earth

I will hide

My passion of rage and tears.

I will woo you

With the selfish voice of reason

And you will also

Begin to know that Mystery.

—Mary de La Valette 